\title{
Getting to the top? Careers of women in psychiatry
}

\author{
Jo Jones and Amanda Poynton, Collegiate Trainees' Committee
}

The 1990 Trainees' Forum was held during the Winter Quarterly Meeting and was attended by over 60 people. The choice of topic reflects the longstanding concern of the Collegiate Trainees' Committee about training for women doctors in psychiatry. There were three speakers: Dr Isobel Allen, who has extensively researched doctors' careers (Allen, 1988); Dr Barbara Ely, a Senior Medical Officer at the Department of Health; Dr Margaret Oates, a Consultant Psychiatrist and Senior Lecturer in Nottingham.

\section{Research findings: doctors and their careers}

Dr Allen had identified three cohorts of medical graduates and interviewed them with respect to their career patterns and difficulties. Both men and women complained of constraints on their careers in terms of the scramble for jobs, the need to be geographically mobile and the increasing rigidity of the career structure; male and female attitudes showed increasing similarity in the later cohorts. There was a general lack of knowledge and understanding about parttime training options for women. Dr Allen remarked that few people appreciated that part-time posts in medicine would involve more hours of work than many full-time jobs elsewhere.

Doctors of both sexes felt that the current career structure strongly promoted conventional career patterns. Hence women were more likely to be at a disadvantage. Both male and female doctors felt that realistic career advice was lacking. Some respondents felt women in particular should be warned of career problems which they might encounter. However, Dr Allen commented that a potential disadvantage of 'realistic' advice was that it might steer women into less inconvenient options, for example staff grade posts, thereby wasting their talents and resources. She emphasised that women doctors might be deployed more effectively if the medical career structure were changed to allow more flexibility of career paths, particularly during the years when women have young children.

\section{Initiatives from the Department of Health}

Dr Ely is currently working in Medical Manpower and Education, and is secretary of the Working Party on Women Doctors and their Careers which is taking forward some of the recommendations of Isobel Allen's report. Dr Ely sees the Department of Health as facilitating the careers of women doctors in several ways. Firstly, the DoH instigated Dr Allen's research; more research will examine the area of general practice and women doctors. Secondly, the DoH has set up a working party to consider the results of the research and existing schemes for those with domestic commitments i.e. the Doctors' Retainer scheme and the PM(79)3 scheme. The former is a modest scheme, intended to be used in the short term only, with funding as a contribution to expenses. The PM(79)3 Senior Registrar competition is centrally operated by the DoH. Candidates who pass a national appointments committee receive a manpower approval, and then have to arrange a post and its funding and satisfy a local appointments committee in that region. (See Working Party of Collegiate Trainees Committee, 1987; Livingston, Ogelthorpe \& Robertson, 1988). The PM(79)3 approvals are allocated by specialty, and for senior registrars are top sliced from the JPAC Senior Registrar National Targets i.e. a certain percentage of Senior Registrar National Target will be set aside for part-time training. Dr Ely commented that the DoH had shown flexibility in allowing the part-time quotas to drift upwards until the next review when there has been high demand. With the new arrangements for registrar training, based on Achieving a Balance - Plan for Action (DHSS, 1987) there will be a registrar part-time topslice for each speciality, of around $5 \%$. The Registrar scheme will be run regionally.

\section{An insider's view}

Dr Oates works in a district where there are a number of women psychiatrists. While several of the consultants had trained part-time, there are relatively few current part-time trainees. She believes that the local demand for part-time work is decreasing and speculated that this is due to some of the problems with existing part-time training schemes.

The problems faced by women working part-time include the necessarily prolonged training, increasing age compared with full-time peers and the difficulty in having one's career taken seriously - not just at work but also at home. The work is much more than half time, and most of the salary is used in 
paying for child care. Furthermore, these doctors usually work many more hours than they are paid for, they have little time for interaction with peers and with clinical teams, and elective and research sessions are vulnerable to erosion. Education often takes place out of hours, if at all. There is additional performance pressure to overcome perceived negative attitudes to part-time working.

A second rate role for women in medicine is perpetuated by the process of training, the attitudes of female doctors to each other and the politics of marriage. Currently adopted solutions force women to be more like men at work and the vulnerable situation of women may be exploited resulting in the channelling of women into unattractive specialities or geographical areas.

Dr Oates explored particular attitudes which in her view need to change; these include the attitudes of others and also of women themselves about their own abilities. For example women may tend to view themselves as facilitators rather than leaders, have difficulty in delegating and take nurturing and mothering roles at work. Overall the most important attitudinal change required is the acknowledgement of the value of home and family life and that careers in medicine should be designed to be compatible with such values.

\section{Comment}

The implications for the College are that it should promote career flexibility and part-time training opportunities for both women and men and should question and seek to rectify the absence of such opportunities. The demands of a life outside medicine, particularly those of a family, should be seen as legitimate, healthy and a positive attribute for a doctor.

One third of the members of the Collegiate Trainees' Committee (CTC) are women (Junaid, 1990). This Committee seeks to promote trainees' views within the College and has as major concerns career structure and training. It will continue to press for improvements in the career structure in psychiatry of particular relevance to women and also as part of making medicine fit to practice for doctors of either sex. In view of this, the CTC would be pleased to hear from trainees who are experiencing career problems, particularly those who are trying to balance a career with domestic commitments.

\section{References}

Allen, I. (1988) Doctors and their Careers. London: Policy Studies Institute.

A Working Party of the Collegiate Trainees' COMMITtee (1987) Part-time training in psychiatry. A brief guide to the options available. Bulletin of the Royal College of Psychiatrists, 11, 137-142.

Livingston, H. M., Ogelthorpe, D. \& Robertson, S. (1988) Part-time senior registrar training in psychiatry a feasible option? Psychiatric Bulletin of the Royal College of Psychiatrists, 12, 523-525.

Department of Health and Social Security. Joint Consultants Commitree. (1987) Hospital Medical Staffing: Achieving a Balance: Plan for Action. London: DHSS.

JuNAID, O. (1990) Working for trainees: The Collegiate Trainees' Committee. Psychiatric Bulletin, 14, 636-637.

\section{Election of President}

\section{Notice to Fellows and Members}

Fellows and Members are reminded of their rights under the Bye-laws and Regulations, as follows:

\section{Bye-law XI}

The President shall be elected annually from among the Fellows.

\section{Regulation XI}

(1) As soon as may be practicable after the first day of January in any year the Council shall hold a nomination meeting and shall ... nominate not less than one candidate and not more than three candidates. ...
(2) Between the first day of January in any year and the date which is four clear weeks after the nomination meeting of the Council, written nominations, accompanied in each case by the nominees' written consent to stand for election, may be lodged with the Registrar, provided that each such nomination is supported in writing by not less than twelve Members of the College who are not members of the Council.

(3) An election by ballot shall be held in accordance with the provisions of the Regulations.

The nominating meeting of the Council will be held on 15 January 1990 and the last date for receiving nominations under (2) above will therefore be 11 February 1990. Professor A. C. P. Sims is in his second year of office as President and is therefore eligible for re-election. 